\title{
The Collaborative Terrain of Collective Narratives, Students’ Knowledge, Teaching and Learning
}

\author{
Farhat Shahzad \\ Faculty of Education, University of Ottawa, Ontario, Canada \\ E-mail: fshah024@uottawa.ca
}

Received: Feb. 14, 2013 Accepted: April 9, 2013 Published: February 1, 2014

doi:10.5296/jse.v4i1.3262 URL: http://dx.doi.org/10.5296/jse.v4i1.3262

\begin{abstract}
The purpose of this qualitative study was to explore the relationships between students' conceptual knowledge, collective narratives, teaching and learning. The study was based on empirical data generated from ninety-nine narratives, four interviews, and demographic questionnaires. The findings highlighted that collective narratives reflect the narrative arcs that encompass the patterns of students' thinking. Collective narratives can be used to assess the organization of students' prior knowledge maps regarding any subject due to their specific internal structures. The author argued that the collective narratives of students create a collaborative landscape of teaching and learning where students' prior knowledge combined with academic knowledge can be imparted in a systematic way. The study concluded that students' collective narratives offer teachers the benefit of using students' texts as alternative thinking devices in constructing knowledge.
\end{abstract}

Keywords: Collective narratives, Narrative arcs, Knowledge construction, Teachers, Students 


\section{Introduction}

"Maybe the stories can help young people to learn our own history and find a place to stand" (Louis Bird, 2005).

Bird (2005), a distinguished Aboriginal storyteller and historian, has documented how the Swamp Cree people (Aboriginal Canadians) teach, learn, and construct knowledge of their history, culture, and values through collective narratives. Following his footsteps, the paper documents how a group of Canadian students remember, learn, and construct knowledge of a historical event through collective narratives. The research questions are: How do the collective narratives of students grasp and incorporate conceptual knowledge about the War on Terror? What are the implications of using the students' collective narratives as a tool in teaching a group of diverse learners with multiple levels of preconceptions/misconceptions about a topic/ subject?

In this paper, the term collective narrative means those narratives generated by a group of 99 university students through the processes of collectively remembering and documenting their memories, experiences, and understandings of the war. The approach adopted in this paper is that of collective narrative as a learning tool. The purpose of the paper is to attend to the process and not the content of the narratives. Hence, the war serves only as one possible example, which can easily be replaced by different topics/goals/subjects. The first section of the paper lays out the theoretical framework and the methodology. The next section presents the findings of the study that highlight how collective narratives permeate students' knowledge about an important historical event and how narrative arcs develop without the students' awareness. This section presents a model on learner rendezvous based on a network of concepts and processes that contribute to knowledge construction. The paper discusses how and in what ways the model offers teachers powerful and accessible means of understanding the ways in which their students, who may have experienced learning across a range of educational settings, can construct knowledge about a topic or a subject. Moreover, they learn how to use students' collective narratives in making any subject come alive for them by connecting both their prior conceptual knowledge and misconceptions to the content teachers want to teach. The study concludes that the identification of students' collective understandings and knowledge maps through their collective narratives can provide important information to both educational researchers and teachers for the re-design of future curriculum, research, and teaching/learning practices.

\section{Literature review}

Various paradigms have been developed over the years, including biomedical (Erikson, 1980), psychological (Piaget, 1973), critical (Giroux \& MacLaren, 1982), and postmodern (Kenway \& Bullen, 2001), to understand the relationships between teaching, learning, and curriculum (Stevens, Hunter, Pendergast, Carrington, Bahr, Kapitzke \& Mitchell, 2006). Narratives have not only been used and tested within these paradigms to evaluate and infuse these discussions with rich, reliable results, but have also frequently served as a model for teaching and learning across the boundaries of disciplines, professions, and cultures (Witherell \& Noddings, 1991). An understanding of this collaborative terrain of narratives, teaching and 
learning can lead to new insights and the construction of communal knowledge that will inform teaching practices and educational research in many ways. In other words, classroom discourse, narrativity, and knowledge construction cannot be separated from each other.

The narratives provided by teachers and textbooks are generally at the center of the classroom discourse. Students are supposed to comprehend and learn these narratives. It is generally assumed that teaching students theories of physics, chemistry or narratives of great explorers will be of great import-at least in raising test scores, however, they are more prone to remember and learn from movies or peers as compared to what teachers, parents and their textbooks teach them, and this is worth thinking about (Schank \& Berman, 2006). No matter how hard teachers work or how much of a command they have on their content and instructional practices, some students show disengagement, while many may forget the narratives easily. It generally happens when students cannot relate the narratives told by their teachers to what they already know, or if these narratives contradict with their pre-conceptions or misconceptions about the topic. To resolve the issue, scholars have argued in favor of promoting classrooms that empower students by giving voice to their experiences (Weis \& Fine, 2000; Fine \& Weis, 2003). One of the methods in empowering students is to convert their voices into the systematic learning tool of collective narrative, as they also "learn by telling stories not just listening to them” (Schank \& Berman, 2006, p. 222).

Throughout history collective narratives have been used to a powerful effect in many social and political struggles (Osler \& Zhu, 2011). In teaching, the gathering of collective narratives is a structured process that focuses on a groups' input regarding a particular issue, theory or problem. Teachers can use a specific set of questions to achieve students' collective understandings of the topic or another more focused input. Collective narratives are not individual stories of personal experiences, rather they are comprised of a network of concepts around a particular topic. They convey a systematic reading of students' prior knowledge and misconceptions as well as the complexity and contradictions of their collective understandings. Pringle (2008) has used collective narratives to examine the viability of introducing Foucauldian strategies to help students think critically. He discussed that collective narratives facilitate a connectedness between students' thinking patterns, knowledge building and teaching strategies. From this perspective, Blackman (2010) explored the collective narratives of Caribbean students with dyslexia to highlight their experiences and the processes that contributed to the building of knowledge. In other research, Thomson (2010) has shown how Keiyo students' narratives of snakes are used in teaching and learning. Their narratives are used to document Keiyo language and construct relevant written science curriculum materials for Keiyo children.

The internal structure of collective narratives helps teachers understand how their students use them as a thinking device to connect different concepts in knowledge construction. Their internal structure shows an interpretable mapping of the concepts students use to make a plot line. According to Trochim (1989), the concept mapping process provides an accurate representation of what people are thinking. Novak \& Cañas (2008) state that concept maps represent knowledge in an organized form. They reflect a systematic relationship between concepts or propositions. Teachers frequently use concept mapping as an antecedent for 
writing essays or narratives about a topic in classrooms. On the other hand, students' essays or collective narratives can also be converted into concept maps (Clariana \& Koul, 2004). For example, Lomask, Baron, Greig, \& Harrison (1992) converted students' essays detailing scientific knowledge into concept maps in a statewide assessment in Connecticut. Their assumption was that the essays and concept maps both capture some of the same information about students' science content and process knowledge.

Collective narratives can be used for organizing memories, ideas, and concepts in order to evaluate the concept maps of a diverse group of people. This quality makes them an effective thinking device for knowledge construction in classrooms, as they can provide teachers and researchers access to the structural patterns of students' concept maps. Teachers can use the structural patterns of concepts maps to make connections between students' prior knowledge, misconceptions and the narratives in the textbooks. Structural patterns of conceptual maps emerge from the emplotment of narratives, which is "a dialectical process between the events being recalled and the theme or purpose of the story" (Mcvee, 2005, p. 167). Emplotment is a term coined by Hayden White in 1978. It means, "the encodation of the facts contained in the chronicle as components of specific kinds of plot structures" (White, 2001, p. 223). Nonetheless, it conveys more than a mere plot structure in collective narratives, rather representing the arrangement of knowledge in a clearly identifiable structure. Ochs \& Capps (2002) point out:

This structure isn't merely optional; it's essential. When people recount the events of their lives to others, they don't spout off disjointed details; they transform those events into narratives of personal experience with a clearly identifiable structure, every single time. (p. 154)

These identifiable structures appear in the form of narrative arcs. A narrative arc is an interconnected network of concepts and ideas within the sequence of events that make up the network of knowledge. A typical version of the narrative arc sequence includes setup, complication, development, resolution, and denouement (Thompson, 1995, pp. 28-29). At the crux of this study is the idea that collective narratives can be used as a vital tool in the construction and assimilation of knowledge in classrooms. These narratives not only help students in navigating, interpreting, and adapting new concepts introduced by teachers, but also highlight their thinking patterns.

\section{Method}

The study formed one of the components of a larger research project completed in 2009. The project investigated how Canadian students construct collective memory of the War on Terror. The study used multiple methods to collect data: written narratives, the demographic questionnaires and four interviews. The study employed a discursive approach, informed by the premises offered in social constructionism (Gergen, 1985) to explore the implications of using students' collective narratives for knowledge construction, teaching and learning. A plain language statement and informed consent form were used in accordance with university ethics approval for students and their professors to ensure that they were suitably informed of the purpose and intended outcomes of the research. 


\subsection{Participants}

The participants were 99 first year university students enrolled in different departments of the Faculty of Arts of an urban university in Canada. All participants were recruited through their professors. The author was not affiliated with their Faculty. In order to recruit participants, the author contacted the professors and took their permission to collect the data from their classes. At the end of the exercise, the author collected 103 narratives, but excluded four because the study focused only on young people (from 18-27 years old). Two participants' narratives were not included because they were only seventeen year old and the ethics approval applied only to adults. The other two participants were excluded as they were above 30, according to their demographic questionnaires. The selection of the sample offered a wide range of variation within the group regarding their religious, ethnic, cultural, and national backgrounds. Guba and Lincoln (1989) referred to this as “maximum variation sampling” (p. 178). In terms of ethnicity or national variation, the sample comprised of the students who self- identified as: Caucasian-English speaking (62), Caucasian- French speaking (9), African Canadian (9), Danish (1), Israel (1), Filipino (1), Sri-Lankan (1), Chinese (2), Indian (2), Pakistani (1), Arabic speaking (8), Bosnian (1), Aboriginal Canadian (1). In terms of religion, the sample consisted of the participants who identified themselves as: Christian, Catholic, protestant, Anglican, Muslim, Jew, and Atheist. A total of 9 participants were Muslims and 90 non-Muslims. In terms of gender, 70 participants were females while 29 males. Notably, despite the variability in the backgrounds of these participants, they all had in common a strong willingness to participate in the study.

\subsection{Data collection and data analysis}

Data was collected in two phases. The participants filled their consent forms and demographic questionnaires before writing narratives in their classrooms. There was no obligation to fill the demographic questionnaire. If a participant had any reservations, he/she could write a narrative without completing the demographic questionnaire. It should also be noted that the narratives were guided by the following set of questions given to the participants before the writing exercise:

1. Write a short essay on the course of the War on Terror from its beginning until today, the way you see it, you remember it and you experienced it.

2. How has the war affected you?

3. From where did you get your information about the war?

4. Which sources are the most important for your understanding of the war?

The main instrument of data collection was written narratives. The rationale to use narratives was situated in the compelling arguments made by scholars for including narrative practices to understand youth in elementary, middle, and high school settings (Daiute, 2000, Daiute \& Buteau, 2002; Fine \&Weis, 2003; Shultz, Buck, \& Niesz, 2005; Weis \& Fine, 2000). The evolving narratives of the participants served as the primary source of the interpretive frame.

In the second phase of data collection, the author conducted four interviews, and used the 
same questions given above to expand their narratives. The participants' interviews provided reflective insight into their written narratives by addressing the gaps and omissions (Cross, 2009). Each interview was lasted between one to two hours. All interviews were audio-recorded and later transcribed verbatim. Data gained from the interviews was integrated into the written narratives of four participants. In the process of data analysis, patterns in the narratives were noted in a non-discriminate manner based upon the frequency and consistency of concepts and perspectives reported in the text. Four major patterns were identified and then organized under separate categories. Each category contained a cluster of concepts that pertained to the broader conceptual map. An integration of ninety-nine narratives, four interview responses and the demographic questionnaire information allowed for collective narrative analysis. Narrative analysis is now frequently used in educational research and its significance is being vigorously discussed (see Narrative Inquiry, 2006, Number 1). For the purpose of the analysis in this paper, excerpts from the narratives of 8 students are included. The focus of the analysis is the internal structure of narratives instead of their content.

\subsection{Limitations of the study}

Bearing in mind the findings of this study, it is necessary to indicate its limitations. All participants involved in this study were taking higher education courses. They did not represent each and every section of university students or the larger society. The study was conducted in just one urban university in Ontario and based on purposefully selected participants. The focus of the narratives was to document a group's collective understandings rather than establishing a verification or generalization of events that occured.

\section{Results}

A total of 90 out of 99 students' collective narratives featured Bruner's “dual landscape”. At the first level of the landscape, a network of concepts was appeared and at the second level, the narrative arcs were emerged from the students' re-interpretive acts (Rolling, 2010). These narrative arcs represented the students' conceptual maps about the topic given to them. Four clear patterns or arcs emerged in their narratives that reflect the structural patterns of the conceptual maps. These are discussed below under four broad categories of findings. These arcs were an inherent part of the way students constructed knowledge about the war. Nonetheless, it does not mean that these narrative arcs reflect richly structured and propositional knowledge, as it is the characteristics of teachers' conceptual maps.

4.1. First Version of the Narrative Arc sequence appeared in 39 narratives and comprised of the following formulation: 9/11; the war in Afghanistan; the war in Iraq; and deaths. The following excerpts taken from two different narratives reflect this version:

Following [the] attacks on the World Trade Centre on the day of September 11, 2002 [sic], I can remember three things that affected the world: [The] American attack on Afghanistan, additional security measures, and [the] attack on Iraq. I think that the world is controlled and manipulated by some powerful countries. They are free to do anything in the name of security and 
crushing terrorism. The net result is nothing but deaths. (19 year old female and first generation immigrant from China)

The course of the war on terror, to me anyway, began on September 11, when the planes were hijacked and crashed. [The] U.S. invaded first Afghanistan and then Iraq. Unfortunately this never-ending hunt has brought upon death to thousands of people all around the world. (English speaking, 18 year old male student)

The above passages show a particular structural pattern that appears in the form of an arc. This arc is made up of three major segments: a starting point, central conflicts or development, and an ending point or a conclusion. The starting points of the arc are the events of 9/11, while the wars in Afghanistan and Iraq appear as central conflicts in the arcs. The last segment is the ending point or the moral, which provides an interpretative reading of the representations of the war available to these students. There is an organization of concepts around different nodes of the arc that reflects the students' conceptual framework. An interwoven structure appears in the form of cause and effect relationships in these narratives. For example, how the events of 9/11 became the cause of the attacks on Afghanistan, Iraq, and the intense security measures. Within this colossal web of relations, different concepts such as 'terrorism', 'control', 'manipulation', 'never-ending hunt', or 'security' appear. At the same time, we can also find misconceptions about the war in the second excerpt such as representing the Americans as those solely responsible for everything related to the war.

4.2. Second Version of the Narrative Arc sequence appeared in 27 narratives and comprised of the following formulation: a vague war; mobilization of the war through the U.S. invasion of Iraq and Afghanistan; an unjust war that gave the U.S. an excuse to invade other countries. This version of narrative arc can be seen in the following excerpts taken from two narratives.

It is a vague war since it's beginning. Not for one second I was afraid of terrorists because I felt that fear is used as an instrument that keep the people in a continuous state of insecurity. From the start, I understood that Saddam Hussain has nothing to do with it, as [the] Americans wanted us to believe. [The] Americans decided to defeat terror with terror and thanks to the Bush Doctrine they are spending billions of dollars in Iraq and Afghanistan on the name of crushing terrorism. They are killing people and pretending that it has something to do with 9/11. It never seemed a justified war to me. (French speaking, 19 year old male student)

My understanding of the war is as vague as the term is. It is a distorted war started by politicians to accomplish certain objectives. It has been mobilized through the U.S. invasion of Iraq and Afghanistan. Terror is used as the political fear-mongering tool by the U.S. such as the threat of communism was used from the 50s to [the] 80s to justify the Cold war. It could not be justified as a just war. (18 year old male student and first-generation immigrant from Israel) 
These narratives show another structural pattern of the concepts in relation to the war. The starting point of the arc revolves around a concept "vague" as used by the participants to define the war. Then there is a discussion of the central conflicts in relation to the war but the sequence of events is not chronological as it was in the first version. In this arc, different concepts are linked to the central conflicts such as 'fear', 'security', 'terror', 'a distorted war', 'communism' or 'the Bush doctrine'. Through a cause and effect relationship, this group of participants develops a narrative arc that ends with a conclusion that it is an "unjustified war". The moral of this arc is different from the previous one. The first arc's ending point is the apparent outcome of the war while this one reflects a judgment about the war's nature. This group focuses on the war in Iraq and avoids discussion about the war in Afghanistan or Canada's involvement in it. The same type of misconception (the Americans as the sole villain of the war) appears in this category as noticed in the previous one.

4.3. Third Version of the Narrative Arc sequence appeared in 21 narratives and comprised of the following formulation: 9/11; Afghanistan war; Iraq war; and economic consequences of the war. This version of the narrative arc can be seen in the following excerpts:

September 11, 2001 [is] a date that will live in infamy. I was probably too young to understand the full severity of the situation [then] but looking back now, I can see that this war is all demonic work. People were consumed by fear and anger and it was claimed by our government that the war is waged to give people a sense of comfort and justice. Slowly, however, the nature of the war began to change. Whispers of Saddam Husain's weapons of mass destruction and the threat of Iraq began to creep in the minds of Americans after invading Afghanistan. The war in Iraq began, which eventually became one of the biggest political blunders of all time. Overall it seems that our government is wasting taxpayers' money on a war that does not belong to us. (English speaking, 18 year old female student)

It is an idealism infused war waged to create a sense of accomplishment after being embarrassed on September 11th. From what I have been able to understand, Afghanistan is at a war solely based on a policy to control opium exports, mineral resources, and the region's politics. I am appealed by the fact that [the] U.S.A. and Canada, both [are] trying to convey themselves as heroic countries in Afghanistan. I am glad that Canada didn't join hands with the U.S. in invading Iraq on the name of crushing terrorism. Terror is a very strong fear and most of the time terror is used to control societies in human history. Living in fear 24/7 is not the way one should live. What we have seen so far in the name of this war is that our taxpayers' money has been wasted to control other peoples' land and lives. (19 years old male student with Danish origin)

The narrative arc starts on the day of 9/11. The middle part of this arc is again a discussion of the central conflicts. As compared to the previous two groups, this one discusses the partnership of the U.S. and Canada in the war, instead of portraying only the Americans as the exclusive actor of the story. They do not try to maintain silence about the Canadian role in 
the war or how their own government has used "fear" as a controlling mechanism in the society. In this arc different concepts are linked to the central conflicts such as 'fear, 'anger', 'justice', 'political blunders', 'mistake', 'wastage', 'terror', 'economy', 'embarrassment', 'control', or 'heroic countries'. The concluding part of the arc is different from the previous versions. It focuses on the economic cost of the war as felt by the larger society.

4.4. Fourth Version of the Narrative Arc sequence appeared in 3 narratives and comprised of the following formulation: terrorism as a historical phenomenon; the events of 9/11 bring it to the forefront for the West; wars in Afghanistan and Iraq; and a perpetual war. This version of narrative arc can be seen in the following two excerpts:

The war on terror is such a ubiquitous phrase in contemporary western societies, while the issue has been existed in human history for centuries. Nonetheless, it has truly come to the forefront of Western political debates in the aftermaths of September 11, 2001. Here in Canada, being so far from the wars in Afghanistan and Iraq, I can feel the multidimensional effects of this perpetual war, as it is a highly ideological battle too. (18 year old male student whose parents migrated from Sri Lanka).

The concepts of war and terrorism have always existed in human history. Terrorism existed before $9 / 11$ in the world, but this war on terror started appearing all over the western media after September 11 attacks. This war is based on the propaganda of those who rule the world, and there is no reason to buy into it. They went into Afghanistan and Iraq to promote their economic and political interests. I think this perpetual war is simply politically motivated. (19 year old male and Muslim student whose parents migrated from India).

In the fourth version of narrative arcs, the starting point is totally different from the previous three ones. The events of 9/11 do not appear as the starting point of the narrative arc, rather it starts with an understanding that the events of 9/11 should not be considered as the first incidence of terrorism against humanity. According to this group of participants, terrorism and the fight against it are not new phenomena, and terrorism as a new phenomenon is an illusion that created by the western media and politicians to camouflage their political and economic motives behind the war. The war on terror has been with us since humans have learned to impose terror on each other for the sake of control and power. The middle part is about the central conflicts in relation to the war but the difference is that, this group can situate and interpret the war in a historical context. The moral is that the war is perpetual and terror has always been used to crush terror in human history. Again we can see an interwoven structure in the form of cause and effect relationships in these narratives. For example, how economic and political motives became the cause of the attacks on Afghanistan and Iraq. Different concepts such as 'media', 'a perpetual war', 'ideological battle' or 'terror' appear within this colossal web of relations. 


\subsection{Summarizing the findings}

The analysis reveals four types of concept organization or four narrative arcs in relation to the war. These arcs reflect the structural patterns of the knowledge construction. The participants construct knowledge on the basis of their memories, readings of different cultural texts, and interpretations provided by different interpretative communities (Shahzad, 2011). The arcs emerging from students' re-interpretive acts (Rolling, 2010) depend not only on how different concepts are intertwined and linked together but also on the narrators' power of evaluation. When students create narrative accounts of the war, they seek to convince their readers about the moral justifiability of their re-interpretations in relation to the topic. They are aware of the fact that just like any other war, this war also produces moral atrocities. There are two main differences in these narrative arcs. The first difference appears in the sequence of events used to build the arc. The first and third arcs start with the events of 9/11, though they diverge after that. The second and the fourth arc have different starting points. They start with different perspectives about the beginning of the war as compared to a linear chronological approach appears in the first and third versions of the narrative arcs. The second difference appears in the arcs' concluding parts. The power of conclusion makes them distinct from each other because the conclusion typically sets out the moral and shapes the narratives (Wertsch, 2002). Four morals appear at the end of arcs: the net result of the war is death; it is an unjust war; wastage of economic resources; and it is a perpetual war. These differences show the power of conclusion or ending point in shaping the narrative of the war. These narrators are looking at the same events and characters but reaching divergent conclusions. The following table summarizes the concepts and the cause and effect relationships among them, the students used to construct knowledge in the form of narrative arcs.

Table 1. Concepts and cause and effect relationships in narratives

\begin{tabular}{|l|l|l|l|}
\hline $\begin{array}{l}\text { SIMILAR } \\
\text { CONCEPTS }\end{array}$ & $\begin{array}{l}\text { DIFFERENT } \\
\text { CONCEPTS }\end{array}$ & CAUSE & EFFECT \\
\hline $9 / 11$ & Control & $9 / 11$ & War on Terror \\
\hline War in Afghanistan & Deaths & War on Terror & War in Afghanistan \\
\hline War in Iraq & Vague & War on Terror & War in Iraq \\
\hline Security & Demonic work & War on Terror & Death \\
\hline Destruction & A political blunder & Terrorism & Fear/insecurity \\
\hline Terrorism & A non-justified war & War in Afghanistan & $\begin{array}{l}\text { Wastage of } \\
\text { economic resource }\end{array}$ \\
\hline Fear & A perpetual war & Terror & Terror \\
\hline
\end{tabular}

An in-depth reading of the narratives reveals that each concept has a colossal web of relations. These relations are the grits from which knowledge is constructed. The relationships highlight the students' conceptual knowledge and misconceptions about the topic. This specific nature of collective narratives gives teachers opportunities to redesign their pedagogy in a way that can persuade students to rethink, question and challenge their misconceptions before teaching them topics such as:

Historical, political, cultural, and economic context of wars; 
$>$ The role of power dynamics in wars;

$>$ Selected and contested nature of wars' collective memories

$>$ Peace building/peace-keeping;

$>$ Terrorism; or

$>$ Complexities of international relations.

\section{Discussion}

The exploration of collective narratives' internal structure indicates their potential as a teaching/learning tool. This paper presents a model that teachers can use to assess the organization of ideas, concepts and misconceptions about any topic in a group of diverse students. I do not focus on students' interpretations about the nature or justification of the war, as the war itself is not a focal point in this paper. Rather, I want to highlight how students' collective narratives' internal structures reflect their thinking patterns in a systematic way, thus I framed the analysis in terms of not so much what and how the participants know about the war. The purpose was to show how the structural patterns of interrelated concepts in collective narratives help teachers in gaining access to their students' personal experiences, schema and prior knowledge regarding the subject.

The model presented in the paper divulges the utility of collective narratives for teachers, educational researchers, instructional/ learning activities, and the knowledge construction process. It is a concrete approach that can be used to uncover and document meaningful patterns in the participants' conceptual frameworks. Collective narratives provide an integrated understanding of knowledge maps, generic dimensions and processes that shape people's lives as understood and described by them (Shahzad, 2012). It is an interactive pedagogy that involves students in recalling, interpreting and further crystallizing their lived experiences and knowledge maps eventually into memory representations, often in the form of collective narratives. As an effective pedagogy it depends on building connections between the conceptual knowledge of teachers as experts and an initial understanding, students bring into their classrooms about the subject.

This study offers an insight into the potential that collective narratives have for enhancing educational researchers' and teachers' understanding of the ways in which students experience complex contexts of learning by engaging themselves in an internal dialogue. Students are the most powerful resource available to teachers and engaging them in dialogue can facilitate the development of effective pedagogies for teaching (Blackman, 2010). As a result, teachers can not only improve poor traditional teaching practices (Hobbs, 2012), they can also get access to problems students face both inside and outside the schools. There are several methods to use collective narratives as a pedagogical tool in teaching a group of diverse students with multiple levels of pre-conceptions/misconceptions about a topic or subject. These methods include all-inclusive reading (based on overall understanding of the concepts represented by the narrative arcs), designated reading (based on understanding similarities and differences), and estimated reading (based on understanding cause and effect 
relationships).

These findings have implications for teaching and learning in many ways. First, an organization of knowledge in the form of narrative arcs can provide teachers with valuable insights into the organization of their students' personal experience (Engel, 1995; Keller, Walton, \& Niolopoulou, 2006; Nicolopoulou \& Richner, 2007). Through the organization of their memories, personal experiences, and conceptual knowledge, students find different ways to remember, re-imagine and contest meanings attached to any topic. This approach can be used to construct knowledge about almost anything related to their lives from the perspective of young people in our classrooms, and can tap into youth confusion and disengagement in order to engage them as critical thinkers, writers, and communicators.

Second, collective narratives provide a holistic way to understand knowledge relationships, often providing measurement of students' collective understanding and most strikingly highlighting their misconceptions and preconceptions. They can be used to evaluate the structural pattern of students' conceptual framework as they reflect how knowledge about a phenomenon, a theory or an event is organized in the form of arcs. Teachers can use collective narratives to get access to their students' schema in relation to almost anything about them. As an individual consumes knowledge about a phenomenon, he/she begins to organize knowledge about it by constructing meaningful relationships among themes, facts, and figures rather than accumulating isolated facts. This organization or interrelatedness of themes or facts in memory is called schema (Eggen \& Kauchak, 2007). Teachers need to get access to their students' schema because consuming and attaining new knowledge about a phenomenon is mainly dependent on how the knowledge in our memory is organized (Jonassen, Beissner, \& Yacci, 1993). Collective narratives can provide multiple and sometimes overlapping perspectives, but they also offer the benefit of using students' texts as a tool to get an access to their schema.

Third, another advantage of using collective narratives as a pedagogical tool is that it does not require extensive instructions. It also allows for investigating the previous knowledge present in a large number of students about a particular phenomenon, theory, or the assessment of knowledge in diverse domains. By collecting students' narrative about relevant issues in their lives or about the content teachers want to teach, it is possible to then them in classrooms as a starting point to help teachers in discovering students' initial conceptual maps around the subject.

Fourth, students' collective narratives can be authentic chronicles of their personal experiences that can help teachers to reduce many of the problems our youth face in schools, and to create a classroom “where students' personal experiences intersect with academic knowledge” (Kincheloe, 2005, p. 4). In sum, collective narratives can be rich sources of knowledge about students' pre-conceptions/misconceptions, imagination, creativity, problems and knowledge maps. Furthermore, arcs in students' narratives can be predictive with or without comparison to a master map (McClure, Sonek, \& Suen, 1999). The collaborative narrative making establishes opportunities for students to create cause and effects relationship among different variables, and to establish connection between their prior knowledge and the content they need to learn. The 
process of writing collective narratives expands and improves students' conceptual map and written expression. By including collective narratives in their instructional repertoire teachers can stimulate students' interest in the subject, and foster a supportive learning community as their memories, writing and evaluative skills are both revealed and constructed in this activity. Students' narratives can reveal multiple layers of meaning and teachers can use them as pedagogical knowledge and an extended practice. This type of knowledge is characterized as active processes by which teachers can build up an interactive learning environment in which both teachers and their students can coordinate together to bridge the gap between the teachers' and the students' conceptual frameworks.

\section{Conclusion}

Students always bring their prior knowledge and experiences in the form of small and sometimes alternative narratives to their classrooms. Teaching is always meaningful and emancipatory when teachers are capable of "engaging students in the knowledge production process" (Kincheloe, 2005, p. 3). I conclude that by using collective narratives to construct a collaborative terrain of knowledge production, teachers will not only be able to build a learning community in which everyone has something to teach; but by opening their students to small but different narratives, they will also help them to critically listen, read and engage in dialogue with different narratives. To teach their students the ways of multiple readings and critical thinking, teachers can use collective narratives to create a pedagogical space in which silence can speak instead of suffocating in the dark corners of their classrooms. Their narratives with multiple and sometimes overlapping perspectives can offer teachers the benefit of using students' texts as alternative thinking devices in constructing knowledge. The findings indicated that knowledge appears in the form of different narrative arcs, which in turn reflect the maps of their basic conceptual knowledge about the war. The study suggests that collecting students' narratives of a topic in the curriculum can help teachers to bridge the gap between curriculum as inscribed, curriculum as imparted, and curriculum as learned by the students. The real benefit of using collective narratives as a learning and pedagogical tool does not lie in the teachers' fixation on whether students' narratives present a true experience or not, but rather they need to think instead of the cultural, social and political effects of their students' voices in the process of meaning making.

The model proposed in this study can be used to explore and analyze students' understandings of almost anything related to their lives such as: the perception of math/science and math/science education among students; the effects of psychological/social/cultural patterns on young gay/lesbian/ bisexual students' learning; how students connect the conceptual knowledge of Physics/Biology/Chemistry to the procedural knowledge; how marginalized youth in our schools cope with social categorization and exclusion; or to listen the hyphenated-hybrid voices of immigrant youth and so on. This model has applicability across a number of educational settings where identity, self-assurance, administrative issues and knowledge are being interrogated, such as teachers' collective response to changes in curriculum or administrative policies or pre-service teacher education program to reflect on their expectations and development. 


\section{References}

Bird, L. (2005). Telling our stories: Omushkego legends and histories from Hudson Bay Toronto: Toronto University Press.

Blackman, S. (2010). Who I work with is important': dyslexic students' narratives about the benefits of grouping for instruction in Caribbean classrooms. Support for Learning, 25(1), 4-10. http://dx.doi.org/10.1111/j.1467-9604.2009.01432.x

Clariana, R. B., \& Koul, R. (2004). A computer-based approach for translating text into concept map-like presentations. A. J. Cañas, J. D. Novak, F. M. González (Eds.), Concept Maps: Theory, Methodology, Technology, Proceedings of the First International Conference on Concept Mapping, Editorial Universidad Pública de Navarra. Pamplona, Spain. cmc.ihmc.us/papers/cmc2004-045.pdf

Cross, B. (2009). Hearing Out Children's Narrative Pathways To Adulthood: Young people as interpreters of their own childhoods in diverging working-class Scottish communities. Childhood, 16(3), 335-353. http://dx.doi.org/10.1177/0907568209335314

Daiute, C. (2000). Narrative sites for youth's construction of social consciousness. In L. Weis \& M. Fine (Eds.), Construction sites: Excavating race, class, and gender among urban youth (pp. 211-234). New York: Teachers College Press.

Daiute, C., \& Buteau, E. (2002). Writing for their lives: Children's narrative as supports for physical and psychological well-being. In S. J. Lepore \& J. M. Smyth (Eds.), The writing cure: How expressive writing promotes health and emotional well-being (pp. 53-73). Washington: American Psychological Association. http://dx.doi.org/10.1037/10451-003

Eggen, P., \& Kauchak, D. (2007). Educational psychology: Windows on classrooms (7th ed.). NJ: Prentice Hall.

Engel, S. (1995). The stories children tell: Making sense of the narratives of childhood. New York: Freeman \& Company.

Erikson, E. (1980). Identity and the life cycle. Norton: New York.

Fine, M., \& Weis, L. (2003). Silenced voices and extraordinary conversations: Reimagining schools. New York: Teachers College Press.

Gergen, K. J. (1985). The social constructionist movement in modern psychology. American Psychologist, 40(3), 266-275. http://dx.doi.org/10.1037/0003-066X.40.3.266

Giroux, H., \& McLaren, P. (1982). Critical Pedagogy: The State and Cultural Struggle. Albany: State University of New York Press.

Guba, E. G., \& Lincoln, Y. S. (1989). Fourth generation evaluation. Newbury Park, CA: Sage.

Hobbs, L. (2012). Examining the aesthetic dimensions of teaching: Relationships between teacher knowledge, identity and passion. Teaching and Teacher Education, 28(5), 
718-727.http://dx.doi.org/10.1016/j.tate.2012.01.010

Jonassen, D. H., Beissner, K., \& Yacci, M. (1993). Structural knowledge: Techniques for representing, conveying, and acquiring structural knowledge. Hillsdale, NJ: Erlbaum.

Keller, S. L., Walton, M. D., \& Nicolopoulou, A. (2006, March). Narrative performance and the creation of local culture in two preschool classrooms. Paper presented at the annual meeting of the Jean Piaget Society, Baltimore, MD. http://www.piaget.org/Symposium/2006/program.html

Kenway, J. \& Bullen, E. (2001). Consuming children: Education-entertainment-advertising. Buckingham: Open University Press.

Kincheloe, J. (2005). Critical Constructivism Primer. New York: Peter Lang.

Lomask, M., Baron, J., Greig, J., \& Harrison, C. (1992). ConnMap: Connecticut's use of concept mapping to assess the structure of students' knowledge of science. A symposium presented at the annual meeting of the National Association for Research in Science Teaching. Cambridge, MA.

McClure, J., Sonak, B., \& Suen, H. (1999). Concept map assessment of classroom learning: Reliability, validity, and logistical practicality. Journal of Research in Science Teaching, 36(4),

475-492. http://dx.doi.org/10.1002/(SICI)1098-2736(199904)36:4<475::AID-TEA5>3.0.CO;2-O

McVee, M. B. (2005). Revisiting the black Jesus: Re-emplotting a narrative through multiple retelling. NarrativeInquiry, 15(1), 161-195. http://dx.doi.org/10.1075/ni.15.1.08mcv

Nicolopoulou, A., \& Richner, E, S. (2007). From actors to agents to persons: The development of character representation in young children's narratives. Child Development, 78(2), 412-429. http://dx.doi.org/10.1111/j.1467-8624.2007.01006.x

Novak, J. D., \& Cañas, A. J. (2008). The theory underlying concept maps and how to construct them. Institute for Human and Machine Cognition. Retrieved June 17, 2008 from http://cmap.ihmc.us/publications/researchpapers/theorycmaps/theoryunderlyingconceptmaps. htm

Ochs, E. \& Capps, L. (2002). Living Narratives: Creating Lives in Everyday Storytelling. New York: Harvard University Press.

Osler, A. \& Zhu, J. (2011). Narratives in teaching and research for justice and human rights. Education, Citizenship and Social Justice. 6(3), 223-235. http://dx.doi.org/10.1177/1746197911417414

Piaget, J. (1973). The child and reality: problems of genetic psychology. New York: Grossman Publishers.

Pringle, R. (2008). No Rugby—no Fear: collective stories, masculinities and transformative possibilities in schools. Sport, Education and Society, 13(2), 215-237. http://dx.doi.org/10.1080/13573320801957103 
Rolling, J, H. (2010). Art Education at the Turn of the Tide: The Utility of Narrative in Curriculum-making and Education Research. Art Education, 6(12). Retrieved June 18, 2012, form http://syr.academia.edu/jameshrollingjr/papers/194753

Schank, R., \& Berman,T. (2006). Living stories: Designing story-based educational experiences. Narrative Inquiry, 16(1), 220-228. http://dx.doi.org/10.1075/ni.16.1.27sch

Shahzad, F. (2012). Collective Narrative analysis and the understandings of young people. In Gaile S. Cannella and Shirley R. Steinberg (Eds.), Critical Qualitative Research Reader (pp. 524-535). New York: Peter Lang Publishing.

Shahzad, F. (2011). The role of Interpretative Communities in Remembering and Learning. Canadian Journal of Education, 34(3), http://ojs.vre.upei.ca/index.php/cje-rce/article/view/343

Shultz, K., Buck, P., \& Niesz, T. (2005). Authoring "race": Writing truth and fiction after school. The Urban Review, 37, 469-489. http://dx.doi.org/10.1007/s11256-005-0016-0

Stevens, L.P., Hunter, L., Pendergast, D., Carrington, V., Bahr, N., Kapitzke, C., \& Mitchell, J. (2007). Re-conceptualizing the Possible Narratives of Adolescence. The Australian Educational Researcher, 34(2), 107-127. http://dx.doi.org/10.1007/BF03216860

Thompson, J. (1995). The Media and Modernity. Cambridge: Polity Press.

Thomson, N. (2010). Science education researchers as orthographers: Documenting Keiyo (Kenya) knowledge, learning and narratives about snakes. International Journal of science Education, 25(1),89-115. http://dx.doi.org/10.1080/09500690210126587

Trochim, W. M. (1989). Concept mapping: Soft science or hard art? Retrieved June 18, 2012, form http://www.socialresearchmethods.net/research/epp89/Trochim2.pdf

Weis, L., \& Fine, M. (Eds.). (2000). Construction sites: Excavating race, class, and gender among urban youth. New York: Teachers College Press.

Wertsch, J. V. (2002). Voices of Collective Remembering. Cambridge: Cambridge University Press. http://dx.doi.org/10.1017/CBO9780511613715

White, H. (2001). The historical text as literary artifact. In G. Roberts (Ed.), The History and Narrative Reader (pp. 221-236). New York: Routledge.

Witherell, C., \& Noddings, N. (Eds.). (1991). Stories lives tell: Narrative and dialogue in education. New York: Teachers College Press.

\section{Copyright Disclaimer}

Copyright reserved by the author(s).

This article is an open-access article distributed under the terms and conditions of the Creative Commons Attribution license (http://creativecommons.org/licenses/by/3.0/). 